\title{
A liberdade e o poder dos signos uma discussão contemporânea
}

\author{
La libertad y el poder de los signos una discusión contemporánea \\ Signs's liberty and power a contemporary discussion
}

\author{
José Serafim Bertoloto ${ }^{1}$ \\ Paulo Vitor Marques Bernardino ${ }^{2}$
}

\begin{abstract}
Resumo
Os signos configurados em memes, selfies e fake news presentes no ciberespaço, resultado da apropriação e remodelação de elementos culturais, são conteúdos produzidos e compartilhados pelos interagentes em grande quantidade e velocidade na rede. Neste panorama discute-se a noção de pós-verdade, a partir da qual apelos à emoção sobrepõem os fatos objetivos. A predominância da imagem nessas produções e a sua propagação no ambiente digital foram analisadas a partir das teorias de Peirce e Jenkins com a finalidade de possibilitar uma variante de leitura sobre o que circula nas redes sociais digitais e sua relação com o conhecimento geral das imagens no país e no mundo. Na sequência, descrevemos as particularidades dos memes, selfies e fake news a partir de exemplos recentes, especialmente no âmbito político do cenário brasileiro. Por fim, apontamos esses conteúdos, orientados visualmente, como suporte para a socialização de crenças e valores em que a busca de visualizações, comentários e compartilhamentos torna-se mais importante do que a veracidade das informações.
\end{abstract}

Palavras-chave: fake news; memes; pós-verdade; propagação; semiótica.

\section{Resumen}

Los signos configurados en memes, selfies y fake news presentes en el ciberespacio, resultado de la apropiación y remodelación de elementos culturales, son contenidos producidos y compartidos por los interagentes en gran cantidad y velocidad en la red. En este panorama se discute la noción de post-verdad, a partir de la cual los llamamientos a la emoción superponen los hechos objetivos. El predominio de la imagen en esas producciones y su propagación en el ambiente digital fueron analizadas a partir de las teorías de Peirce y Jenkins con la finalidad de posibilitar una variante de lectura sobre lo que circula en las redes sociales digitales y su relación con el conocimiento general de las imágenes en el contexto País y en el mundo. En consecuencia, describimos las particularidades de los memes, selfies y fake news a partir de ejemplos recientes, especialmente en el ámbito político del escenario brasileño. Por último, apuntamos esos contenidos, orientados visualmente, como soporte para la socialización de creencias y valores en que la búsqueda de visualizaciones, comentarios y compartimentos se vuelve más importante que la veracidad de las informaciones.

Palabras clave: fake news; memes; después de la verdad; propagación; semiótica

\footnotetext{
${ }^{1}$ Doutor em Comunicação e Semiótica-PUC-SP, Professor e Orientador do Programa de Mestrado em Ensino na Universidade de Cuiabá - UNIC, Professor Orientador no Programa de Mestrado e Doutorado em Estudos de Cultura Contemporânea - ECCO/UFMT. serafim.bertoloto@gmail.com

${ }^{2}$ Mestre em Estudos de Cultura Contemporânea pela Universidade Federal de Mato Grosso, Especialista em Comunicação Empresarial pela Universidade Metodista e Bacharel em Comunicação Social - Publicidade e Propaganda pelo Centro Universitário Cândido Rondon. paulovitor.cos@gmail.com
} 


\begin{abstract}
Signs configured on memes, selfies and fake news already existente on ciberspace, as results of cultural elements's appropriation and remodelling, are producced contents shared by inter agents in large quantity and high-speed surfing on internet. By this panoramic view argues about the notion on an extra truth, from where emotional appels overcome on the base facts on that true. The predominance of the image on these productions and its dissemination on digital net were analyzed through Pierce and Jenkins theories, as result given possibilities of fresh views on the contents surfing on digital nets and its relationship with the general knowledge of these images on the country and all over the world. In a given order, we are going to be describing these specific characteristics of memes, selfies and fake News from recently examples, specialy on Brazil's politics scenario. At least, we point towards to those contents, closely adviced as tool to embase social beliefs and values just to be seem, commented and shared is more important than the veracity of facts.
\end{abstract}

Keywords: fake news, memes, over true, propagation, semiotics.

\title{
1 - O que é a verdade nas redes sociais digitais?
}

Comunicar na cibercultura é um processo simples, fácil e acessível. Em poucos minutos uma imagem com texto pode ser criada e compartilhada nas redes sociais digitais. Da mesma forma, escrever uma notícia ou opinião sobre qualquer assunto e em seguida colocá-la para circular na rede seja em um site, blog ou rede social. Esse conteúdo tem potencial de ser apropriado por várias pessoas, ressignificado e compartilhado novamente. Enquanto para outros pode servir apenas como fonte de informação.

Nesse contexto, a produção de conteúdo na cibercultura é configurada em novos formatos nos quais as características das interfaces digitais e o conhecimento dos interagentes mesclam-se em nome da eficiência medida em número de acessos, compartilhamentos e comentários. Assim, a "eficácia tende a se sobrepor à verdade, não exatamente usurpando o seu lugar, mas sutilmente identificando-se com a própria verdade” (ACCIOLY, 2010, p. 162).

Então o que é verdadeiro ou falso ao navegar no oceano de memes, selfies e fake news presentes no ciberespaço? Nestes novos contornos, a simulação incorpora a ambiguidade aos signos, opera com base na dualidade e não se prende ao dilema verdade ou mentira (ACCIOLY, 2010). Se partirmos do princípio que verdade não existe, mas persiste enquanto fato, é a verdade de um conceito que se sobrepõe a outros. O que presenciamos é a produção e a propagação de pós-verdades.

O Dicionário Oxford definiu pós-verdade como um substantivo "que se relaciona ou denota circunstâncias nas quais fatos objetivos têm menos influência em moldar a opinião pública do que apelos à emoção e a crenças pessoais".

A "pós-verdade", um elegante étimo composto que pode parecer fruto da mais refinada filosofia contemporânea, mas não vai muito além de "tucanar" a mentira, naquele 
antigo e consagrado sentido de falar difícil, com sotaque tecnocrático, o que pode ser dito de forma simples e direta.

Essa nova palavra que entrou para o léxico mundial em 2016 e fecha o ano em alta, frequentando as mais diversas bocas e páginas do mundo político e jornalístico. Não seria então, exatamente, o culto à mentira, mas a indiferença com a verdade dos fatos.

As pós-verdades circulam na rede em diversos formatos fáceis de criar e de compartilhar devido a estrutura e as ferramentas das redes sociais digitais que permitem aos interagentes criarem mensagens com texto, imagem, vídeo e som. Destacamos, aqui, os memes, as selfies e as fake news.

A predominância da imagem na produção destes e de outros conteúdos, assim como sua circulação no ciberespaço, aderem as tendências das mídias sociais, a saber: o compartilhamento é feito cada vez com menos tempo; as mídias sociais tornaram-se visualmente orientadas; as redes centradas em tópicos tendem a substituir sites centrado em grupos e a predominância de expressões e sinais visuais para fazer "comentários" (FAUSING, 2014, p. 82-83).

Ao desenvolver este trabalho de análise da comunicação e semiótica em tempos contemporâneos que representam o que circula nos grupos e redes sociais pensamos na conjunção de vários métodos que viessem, de certa forma, privilegiar as imagens selecionadas. Acreditamos que cada uma delas em particular requereria uma abordagem própria, de acordo com o conjunto da produção e a técnica empregada pelo seu criador e pela sua intencionalidade.

A direção das análises recaiu sobre as informações concedidas pelos semioticistas russos e pelos escritos do teórico e pragmático Charles Sander Peirce, com a finalidade única de possibilitar uma variante de leitura que vislumbre dentro do recorte proposto, intercambiando-as com o conhecimento geral das imagens no país e no mundo.

\section{Memes, Selfies e Fake News}

Memes, selfies e fake news são produções orientadas visualmente que podem ser usadas como disseminadoras de pós-verdades. Antes de discuti-las, propomos uma rápida reflexão sobre o papel da imagem no processo de criação para a produção de sentidos.

Segundo Peirce, a imagem construída, suscita no espectador, receptor, "sensações de representação de qualquer coisa existente, perceptível, apenas imaginável, ou mesmo não suscetível de ser imaginada" (PIERCE, 0000 apud SANTAELLA e NÖTH, 1998, p. 159). 
No processo de criação com certeza, o criador será conduzido por uma leve sensação abdutiva, na absorção do signo icônico, ou seja, pela primeira categoria peirceana, "a forma daquilo que é como é, positivamente e sem nenhuma referência a qualquer coisa”, e, ainda, “a da presença imediata, do sentimento irrefletido, da mera possibilidade, da liberdade, da imediaticidade, da qualidade não diferenciada e da independência" (SANTAELLA, 1998, p. 143). Porém, durante o processo de criação de imagens figurativas o criador sofre as influências da realidade, das relações, dos acontecimentos, dos efeitos e das coerções que estão no nível da secundidade, que conduzem inevitavelmente para um terceiro, para a categoria do hábito, da lembrança, da representação, da síntese, da comunicação e semiose e da continuidade. De maneira geral, pode-se considerar que "imagens, em geral, podem ser tanto ícones e índices, assim como símbolos" (SANTAELLA, 1998, p. 143). Em Imagem: cognição, semiótica e mídia Santaella e NÖTH (1998, p. 171) afirmam que:

Tendo como propósito figurar o visível e o invisível, as imagens artesanais são basicamente uma figuração por imitação, figuração da imaginação da visão. Imagem - mímese, retendo, na superfície de um espelho, o gesto que visa fundir o sujeito ao mundo. Esse tipo de imagem é, portanto, basicamente a cópia de uma aparência imaginada, funcionando como meio de ligação da natureza à imaginação de um sujeito.

Nesse sentido, Martine Joly (1996, p. 39), em Introdução à análise da imagem, alega que:

\footnotetext{
é possível constatar que o problema de imagem é, de fato, o da semelhança, tanto que os temores que suscita provêm precisamente de suas variações: a imagem pode se tornar perigosa tanto por excesso quanto por falta de semelhança. Semelhança demais provoca confusão entre imagem e objeto representado. Semelhança de menos, uma ilegibilidade perturbadora e inútil.
}

Se a imagem em alguns momentos pode imitar com tamanha perfeição e nessa virtualidade provocar a ilusão da própria realidade, sem o ser, ela se aproxima, por analogia ou por verossimilhança, do real, o que lhe concede o status de um ícone perfeito. Essa semelhança ao que representa pode ser conseguida por meio de recursos mecânicos como a fotografia, o filme e o disco laser, a proliferação delas nas redes sociais via computadores, tabletes e celulares, que são considerados ícones puros pelo fato de emitirem "imagens perfeitamente semelhantes por meio de ondas emitidas pelas próprias coisas”, acrescenta Joly.

A imagem criada necessariamente não precisa ou deve ser narrativa, porém, sempre que se trabalha na tentativa de imitar ou reproduzir a natureza o criador fica impregnado de mimetismo e, em decorrência, sempre a verossimilhança é cabível. O signo icônico da primeiridade, ou seja, um hipoícone, sofre a influência da imagem observada, e 
consequentemente, por semelhança, os artistas (criadores) a reproduzem. Dentro deste universo das qualidades e das semelhanças os ícones têm um alto poder de sugestão.

No nível das aparências "uma imagem é um hipoícone, porque a qualidade de sua aparência é semelhante à qualidade da aparência do objeto que a imagem representa" (BOSSI, 1999, p. 65). No entanto, o hipoícone é suplantado pelas influências da secundidade e da terceiridade no momento em que o criador, enquanto interprete, deixa-se conduzir por influências das normas, códigos e convenções do meio onde vive e que lhe são repassadas por intermédio das crenças, da religião e das informações visuais, ou seja, os conhecimentos adquiridos por intermédio da sua cultura. As de terceiridade são aquelas que são conhecidas e identificadas pelas normas e convenções culturais.

Meme é um termo grego que significa imitação. O termo é bastante conhecido e utilizado no "mundo da internet", referindo-se ao fenômeno de "viralização" de uma informação, ou seja, qualquer vídeo, imagem, frase, ideia, música e etc, que se espalhe entre vários usuários rapidamente, alcançando muita popularidade.

A palavra "meme" se refere a montagens de foto ou vídeo com frases engraçadas que se popularizam rapidamente entre os internautas, principalmente nas redes sociais - como Facebook, blogs, sites, etc.

Muitos relacionam o termo meme à obra O Gene Egoísta, escrito em 1976 pelo zoólogo Richard Dawkins, que define um meme como "uma unidade de evolução cultural" que se propaga de indivíduo para indivíduo. Porém, ao buscar na história da arte Marcel Duchamp (1919) e outros artistas dadaístas no início do século passado, ou mais recente, como Salvador Dali (1942), Andy Warhol (1963), Fernando Botero (1977) e Jean-Michel Basquiat (1983), num processo de modelização da imagem, já o faziam conforme os vários exemplos em Mona Lisa (obra La Gioconda de Leonardo da Vince, 1503-1504; Museu do Louvre, Paris) que no Brasil até virou garota propaganda da marca Bom Bril . 
RELACult - Revista Latino-Americana de Estudos em Cultura e Sociedade

Revista Latinoamericana de Estudios en Cultura y Sociedad | Latin American Journal of Studies in Culture and Society V. 03, ed. especial, dez., 2017, artigo n ${ }^{\circ} 856 \mid$ relacult.claec.org | e-ISSN: 2525-7870

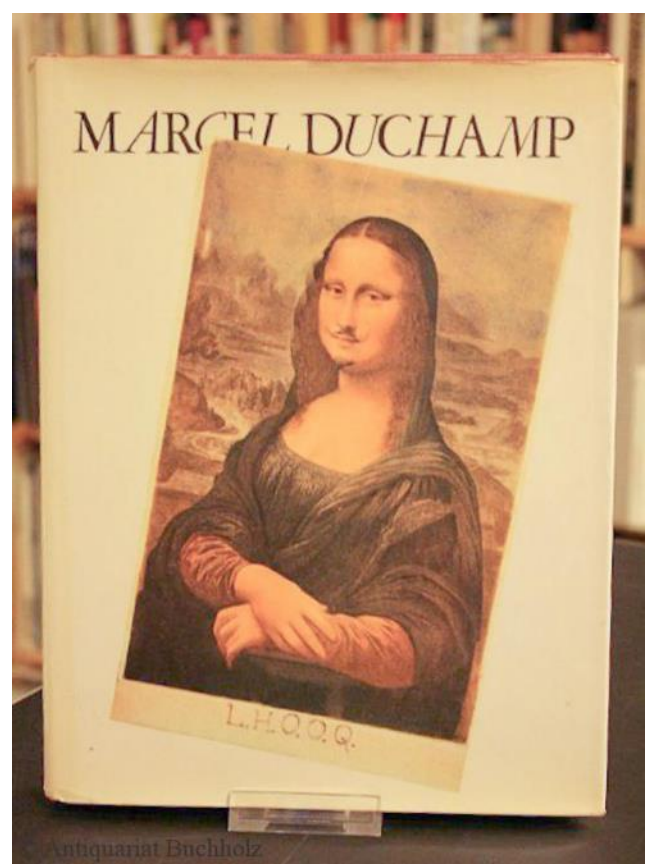

L.H.O.O.Q, Duchamp, 1919

Fonte: Museum of Art Philadelphia, USA

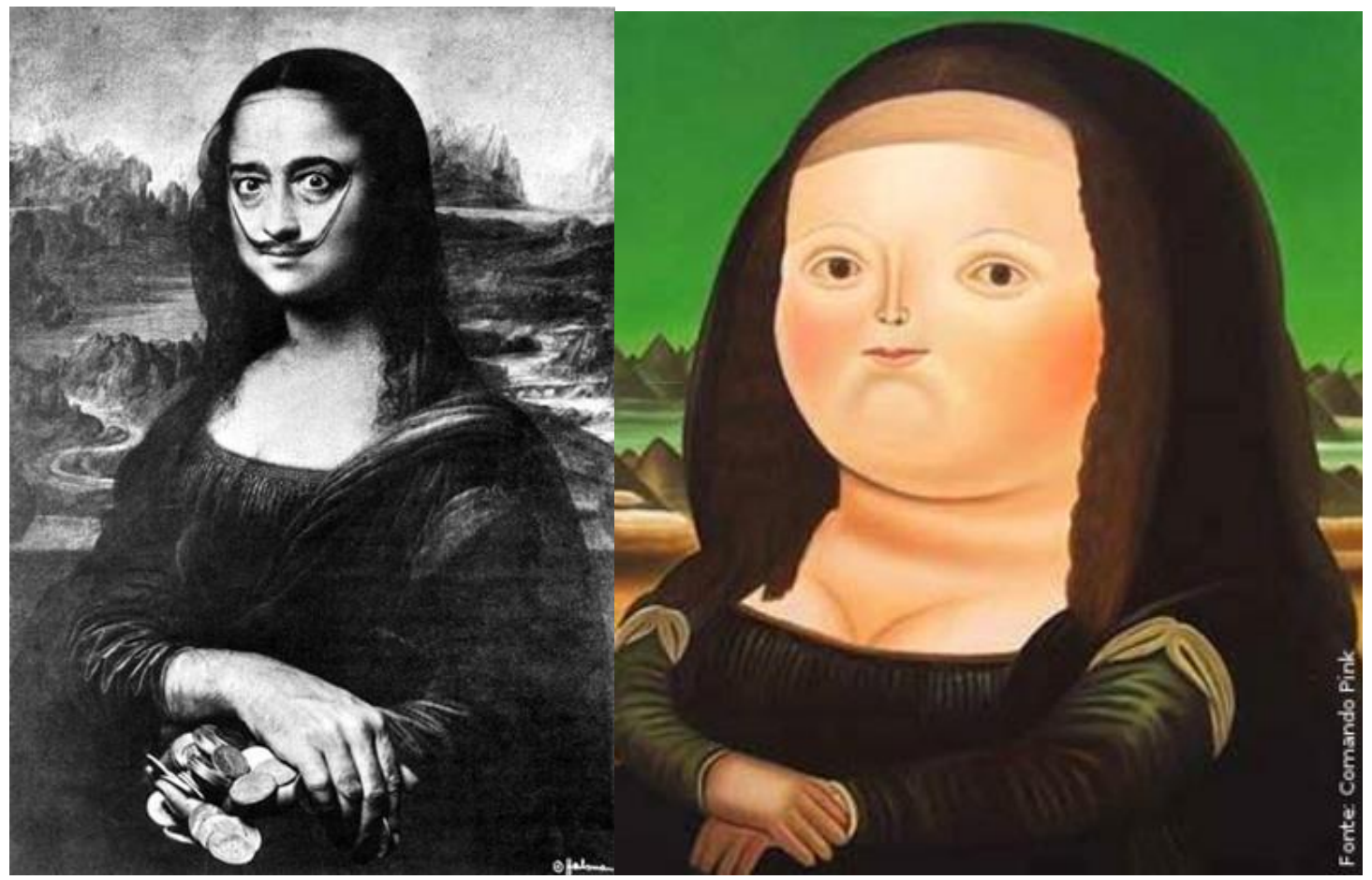

Mona Lisa Salvador Dali 1942

La Monalisa de Botero de 1978 

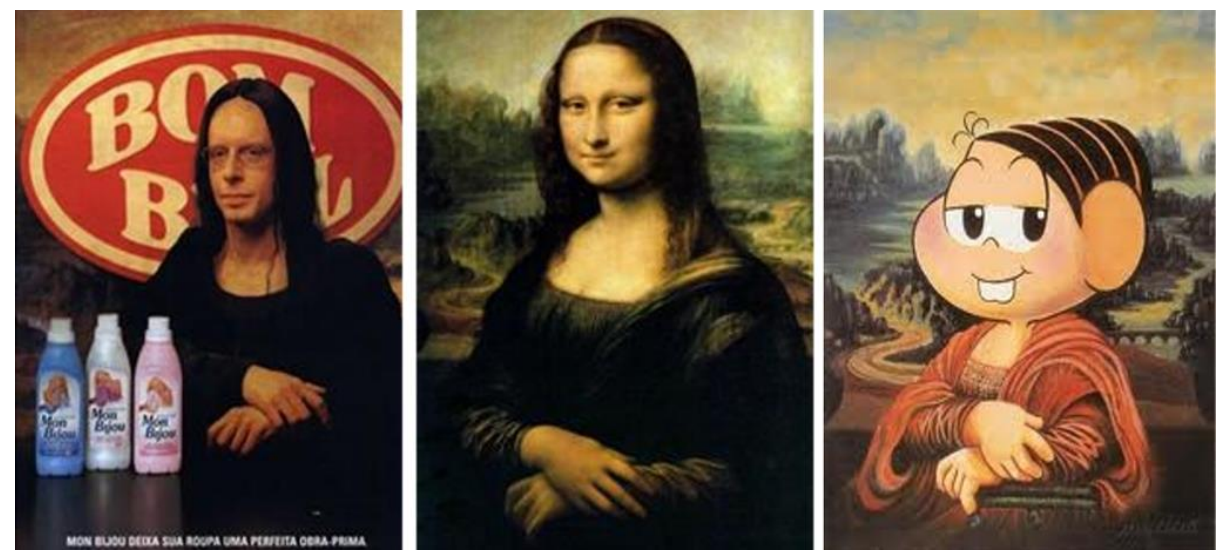

Tela "A Monalisa" usada em campanha publicitária e em revista em quadrinhos Fonte: http://www.propagandashistoricas.com.br/2013/10/mon-bijou-bombril-1998.html e http://turmadamonica.uol.com.br/cronicas/meu-olhar-te-acompanha/

Os memes geralmente são produzidos com base em fatos e eventos cotidianos e podem abordar os mais diferentes assuntos. No Brasil, a produção de memes relacionada à política tornou-se uma constante devido à turbulência que as investigações e delações premiadas têm provocado.

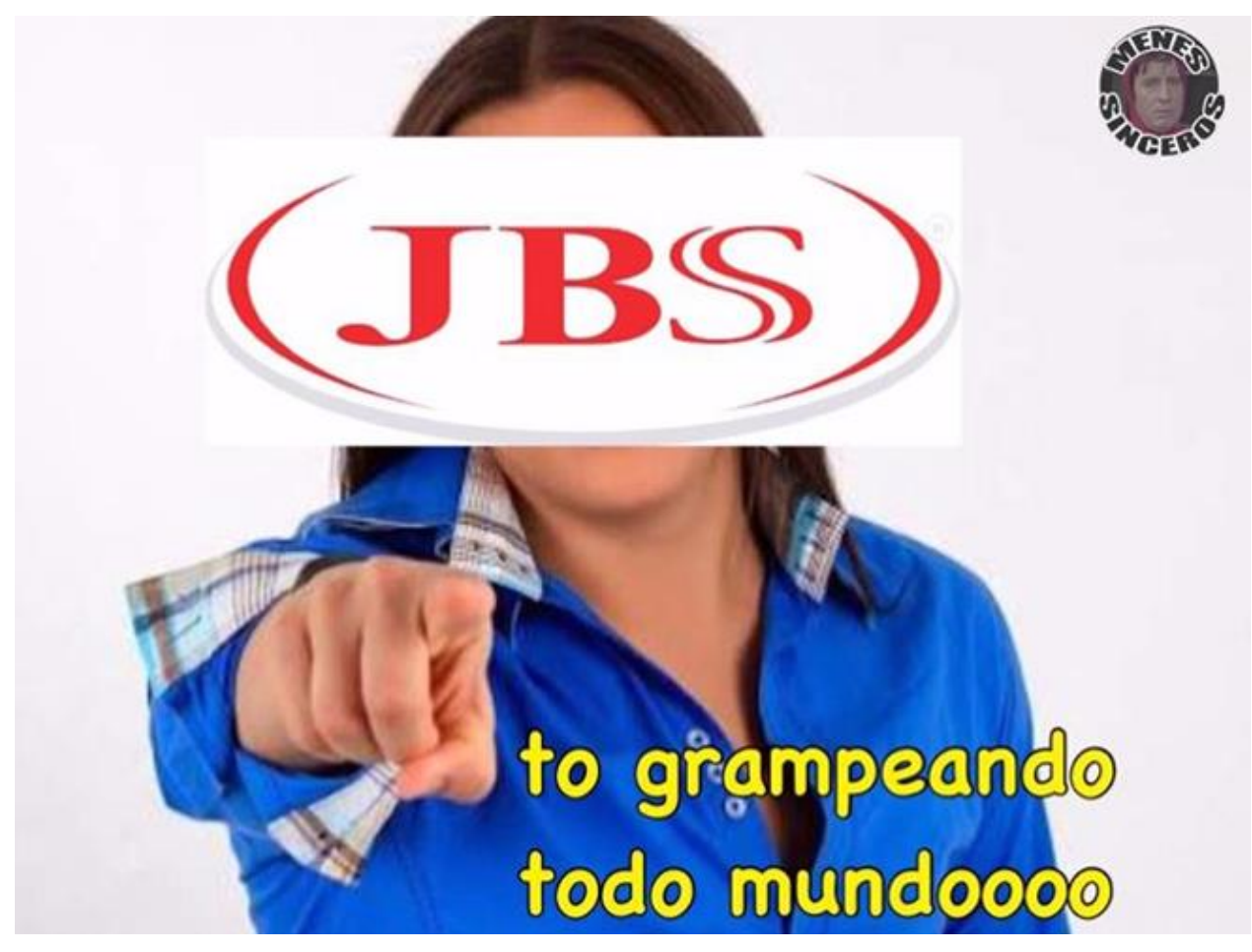

Meme - JBS

Fonte: http://g1.globo.com/politica/noticia/memes-no-celular-e-nas-redes-sociais-a-reacao-da-interneta-delacao-da-jbs-envolvendo-temer.ghtml 
RELACult - Revista Latino-Americana de Estudos em Cultura e Sociedade

Revista Latinoamericana de Estudios en Cultura y Sociedad | Latin American Journal of Studies in Culture and Society V. 03, ed. especial, dez., 2017, artigo no 856 | relacult.claec.org | e-ISSN: 2525-7870

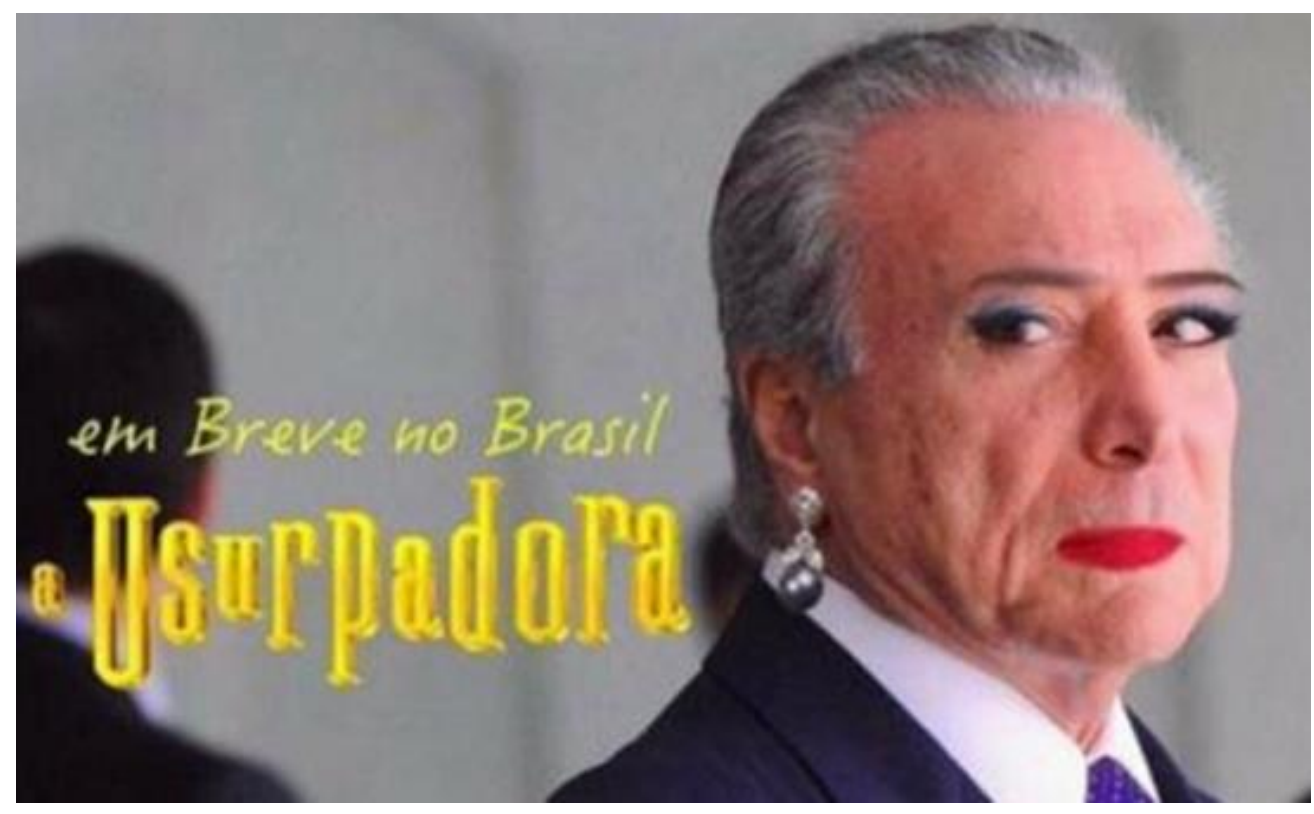

Meme - Temer, A Usurpadora

Fonte: https://bahianoar.com/memes-de-michel-temer-bombam-na-internet-apos-vazamento-de-audio/

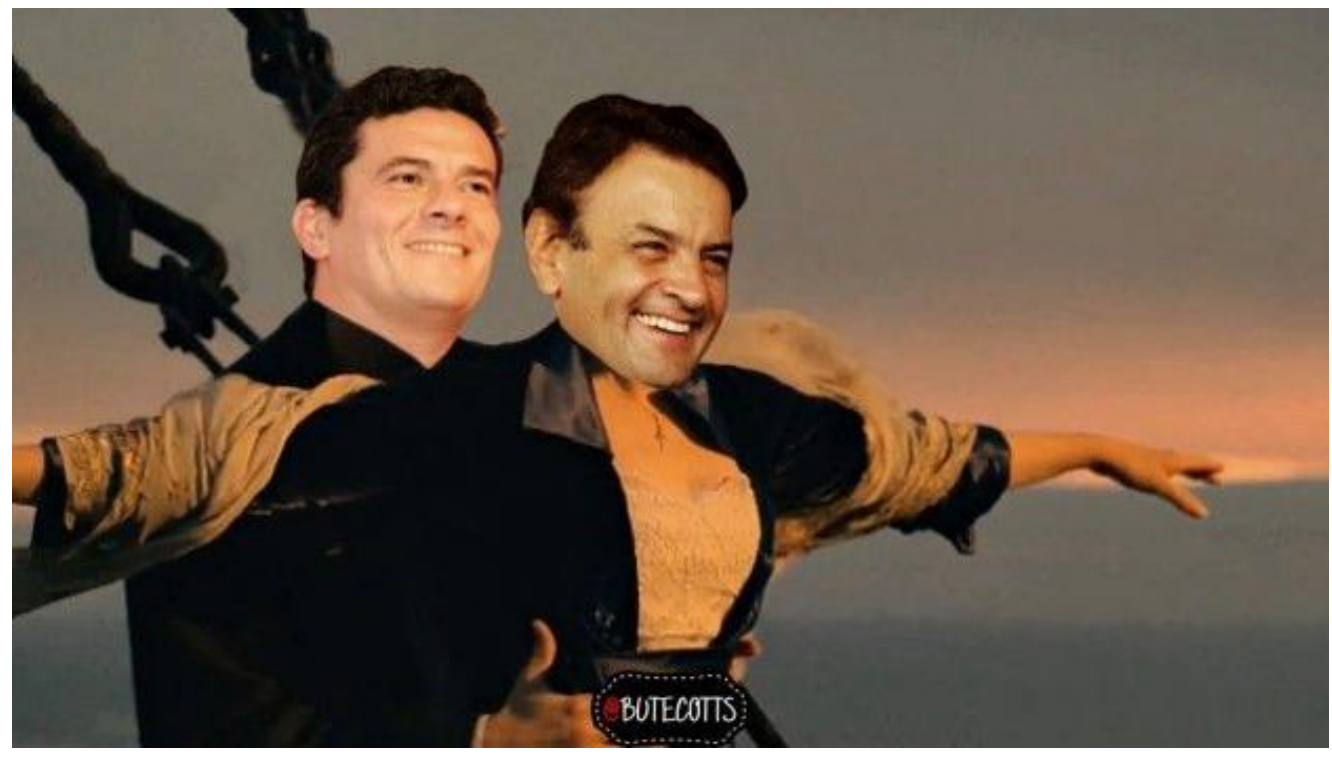

Meme - Aécio Neves e Sérgio Moro

Fonte: http://daqui.opopular.com.br/editorias/geral/pr\%C3\%AAmio-de-brasileiro-do-ano-vai-paratemer-mas-a-foto-de-2016-\%C3\%A9-de-moro-e-a\%C3\%A9cio-1.1191486 


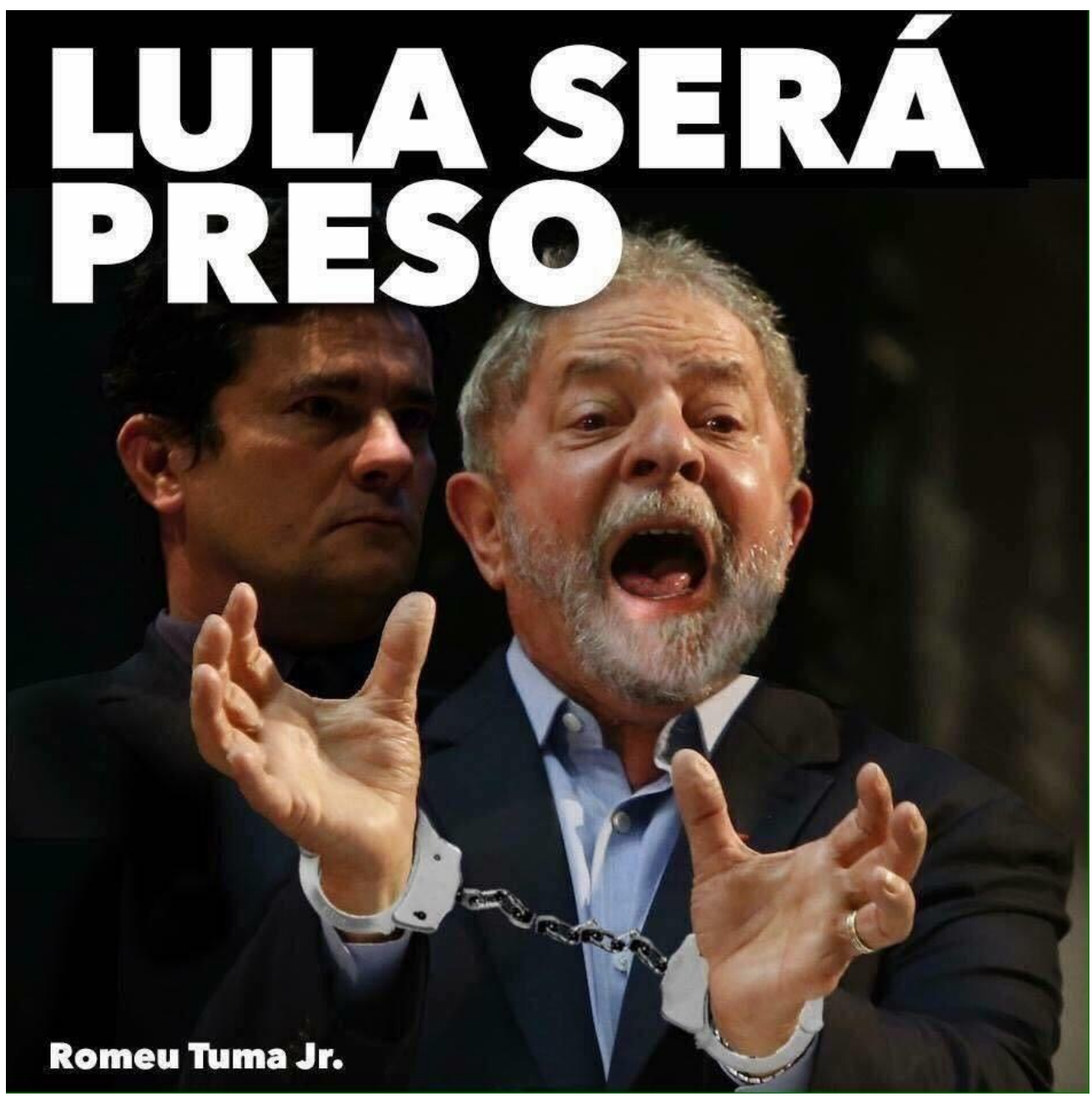

Meme - Lula e Sérgio Moro

Fonte: https://www.megacurioso.com.br/memes-e-virais/98101-os-13-melhores-memes-das-denunciascontra-lula-na-operacao-lava-jato.htm

Vejamos um exemplo recente. Após as gravações realizadas pelo proprietário da empresa JBS envolvendo o presidente, criou-se expectativa sobre o pronunciamento a respeito desse assunto. O jornalista Ricardo Noblat, do site do jornal O Globo, noticiou que Temer iria renunciar. Notícia replicada em outros sites. Durante o pronunciamento Temer enfatizou "não renunciarei, repito: não renunciarei”.

Com base nas imagens e falas do discurso surgiram memes. Dias depois os sites Capinaremos e Ah! Negão, assim como outros sites de humor, receberam notificações da Secretaria de Imprensa do Governo Federal informando que as fotos oficiais "estão liberadas para uso jornalístico e divulgação das ações governamentais, para outras finalidades, é necessária autorização prévia da Secretaria”. 


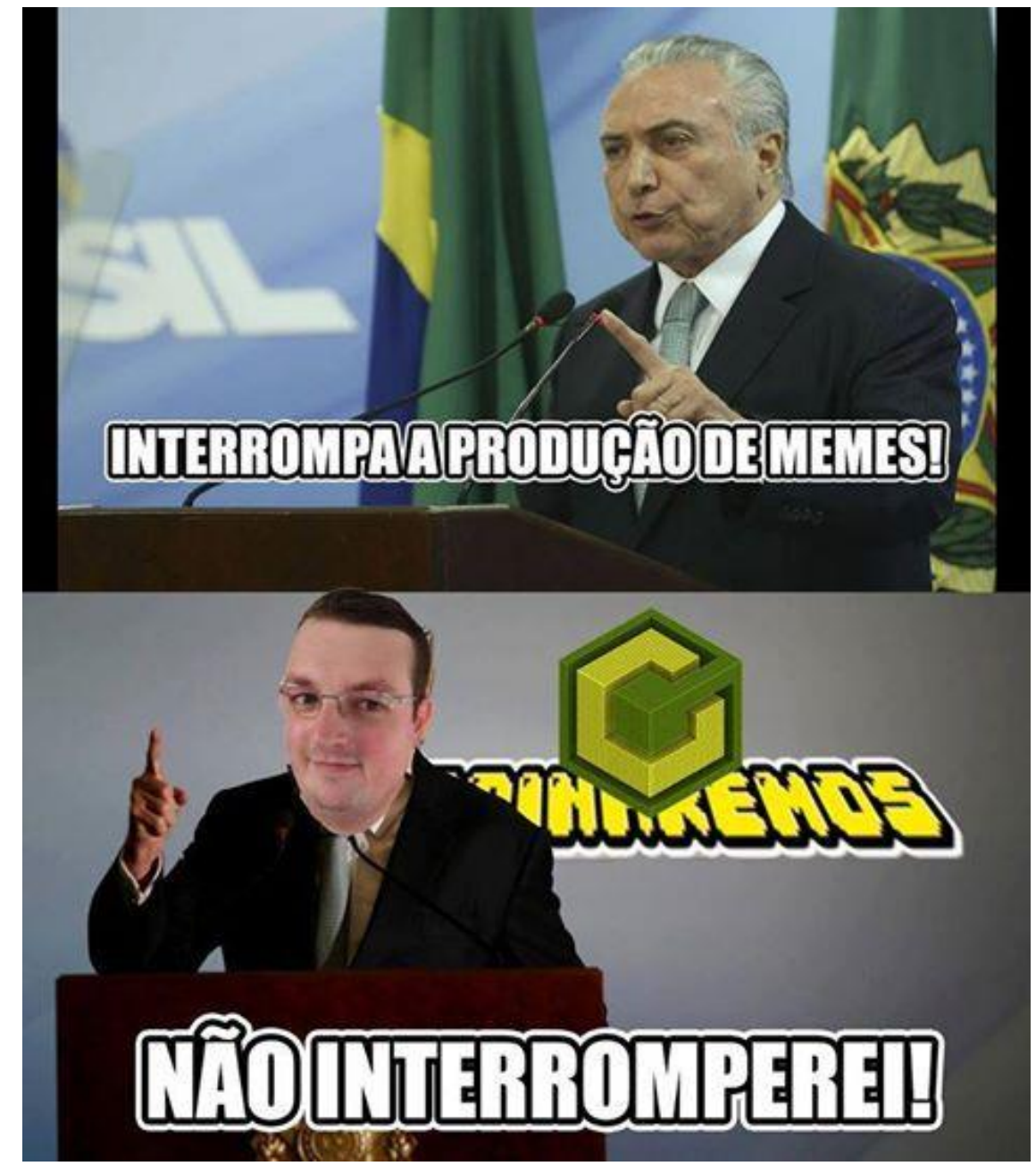

Meme resposta do site Capinaremos, 2017

Fonte: http://capinaremos.com/2017/05/27/o-dia-em-que-o-capinaremos-foi-parar-no-the-new-york$\underline{\text { times/ }}$

A atitude do governo acabou estimulando a criação de memes. Após a repercussão de que o presidente queria "acabar com os memes" a diretoria do Partido dos Trabalhadores liberou um acervo de fotos do Michel Temer para que os internautas usassem livremente.

Assim, um usuário do Facebook pode endossar a mensagem acerca do presidente com apenas um clique seja curtindo ou compartilhando o meme. Para tanto, basta a identificação com suas crenças e valores. Vimos isso nitidamente com a polarização entre os posicionamentos políticos de direita ou esquerda desde a última eleição presidencial.

Outros memes abordam assuntos menos específicos, quase sempre em tom humorístico, como os gifs da personagem Nazaré, a vilã da novela A Senhora do Destino de 2004, ou da Cuca, personagem do Sitio do Pica-pau Amarelo, que ganhou destaque entre os internautas americanos recentemente. 

V. 03, ed. especial, dez., 2017, artigo $n^{\circ} 856$ | relacult.claec.org |e-ISSN: 2525-7870
\#HorarioDeVeraoComecouE acordei 9 mas já era 10 mas que na verdade era pra ser 9 mas que agora é 10

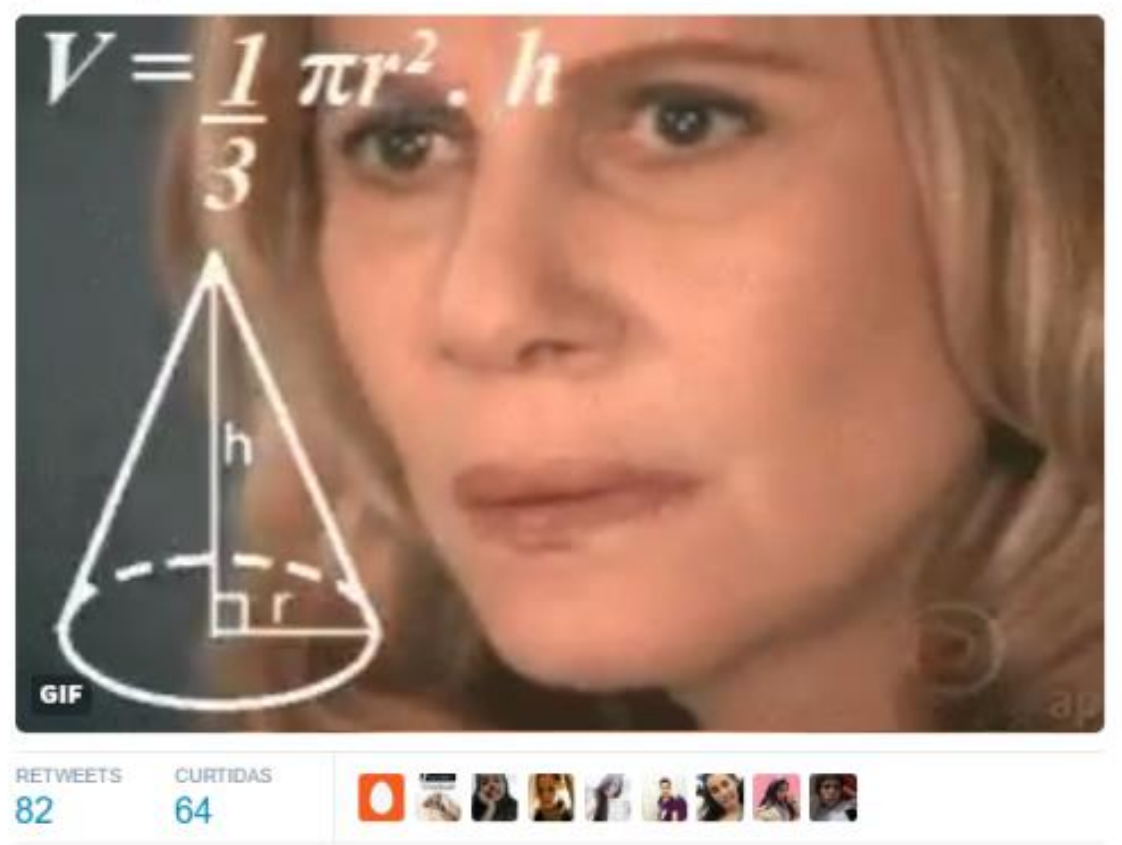

Meme Nazaré Confusa

Fonte: http://www.museudememes.com.br/sermons/nazare-confusa/ 


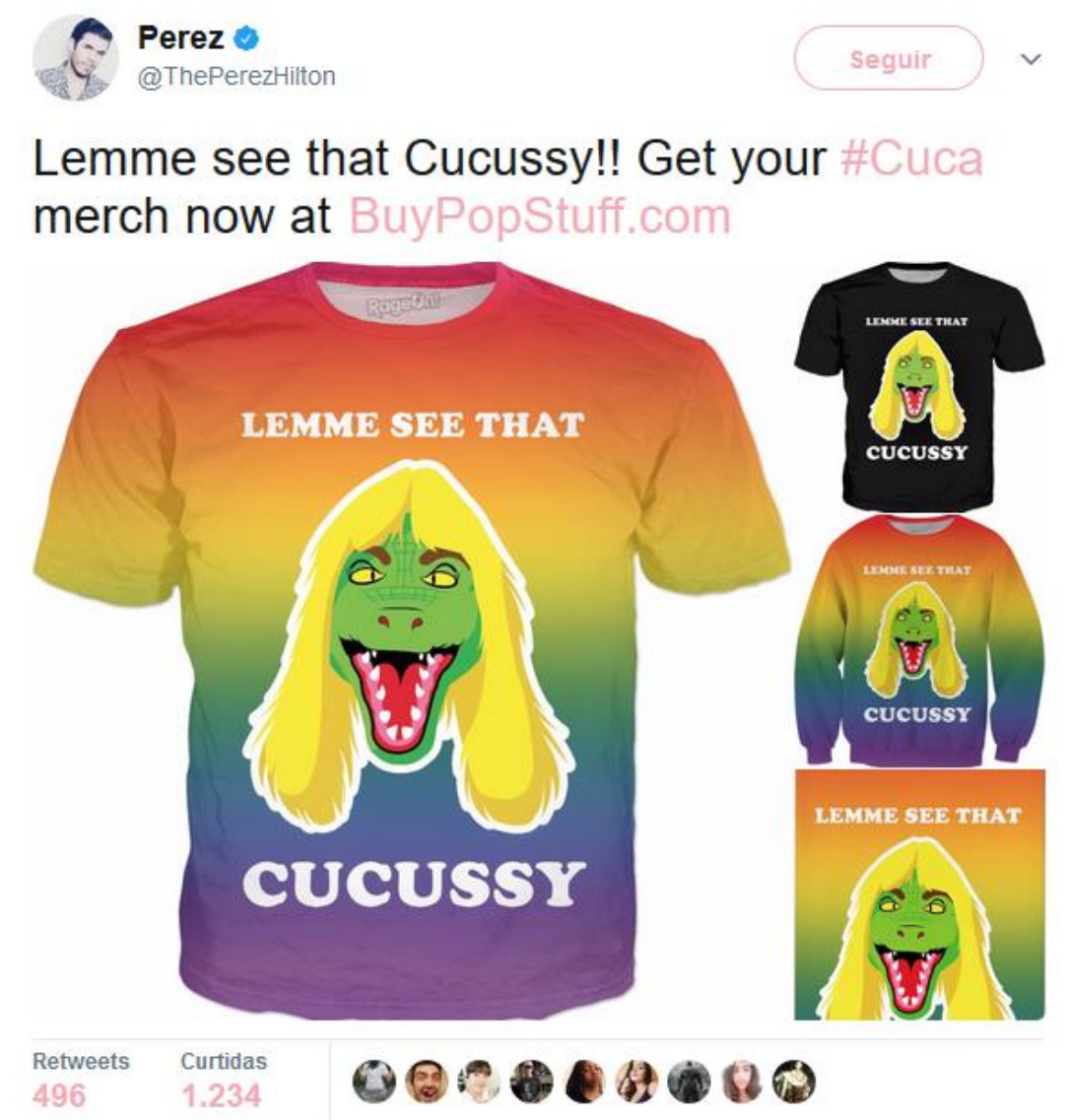

Venda de camisetas com meme da personagem Cuca pelo blogueiro Perez Hilton Fonte: https://twitter.com/ThePerezHilton

Após o sucesso dos memes, o blogueiro do site Perez Hilton colocou à venda camisetas com imagens da personagem e o mesmo está sujeito a ser processo pela Rede Globo e pela família de Monteiro Lobato por uso comercial sem autorização. Nesses dois exemplos, percebe-se que qualquer tipo de conteúdo, seja criado ou não na rede, tem potência para ser transformado em meme quando inserido no contexto digital e acessível aos públicos para construir novos sentidos por meio da remixagem.

Enquanto os memes têm como base a imagem de terceiros, as selfies representam a estética do autorretrato a partir da qual o reflexo, a identidade e o reconhecimento (FAUSING, 2014) são os elementos importantes para visualizar o que se é nas redes sociais.

Dentro do escopo político, produzir uma selfie em alguma manifestação pode transformá-la em mídia, endossando seu apoio. Sendo assim, as selfies, bem como os memes, são produções orientadas para a socialização de valores, crenças e concepções ideológicas.

As fake news ou notícias falsas recorrem a imagens de personalidades, nomes de instituições e até mesmo dados supostamente atribuídos a pesquisas como forma de "atribuir" 
credibilidade a sua mensagem, ainda que o apelo principal seja emocional. A consulta a fonte e a verificação das informações perde espaço e até a relevância em tempo de pós-verdades

No Facebook é comum encontrar imagens com pessoas conhecidas - artistas, políticos, escritores - com frases supostamente ditas por elas. Seguindo essa tendência a página Sensacionalista - Um jornal isento de verdade - no Facebook cria notícias falsas com base em notícias recentes. A proposta da página sempre foi clara, o interessante é que em muitas publicações é possível observar comentários de pessoas que acreditam na veracidade da mesma.

Ainda no Facebook, os algoritmos da plataforma, aliado aos filtros que o usuário pode definir, tendem a criar uma espécie de bolha narrativa, pois o feed de publicações mostrará apenas informações coerentes com a sua linha pensamento, assim como fontes semelhantes dificultando o acesso a contrapontos aquilo que está sendo divulgado.

As notícias falsas também podem assumir outros formatos, como os memes, por exemplo, a montagem animada (gif) com o Papa Francisco batendo na mão do presidente americano Donald Trump ao posarem para uma foto.

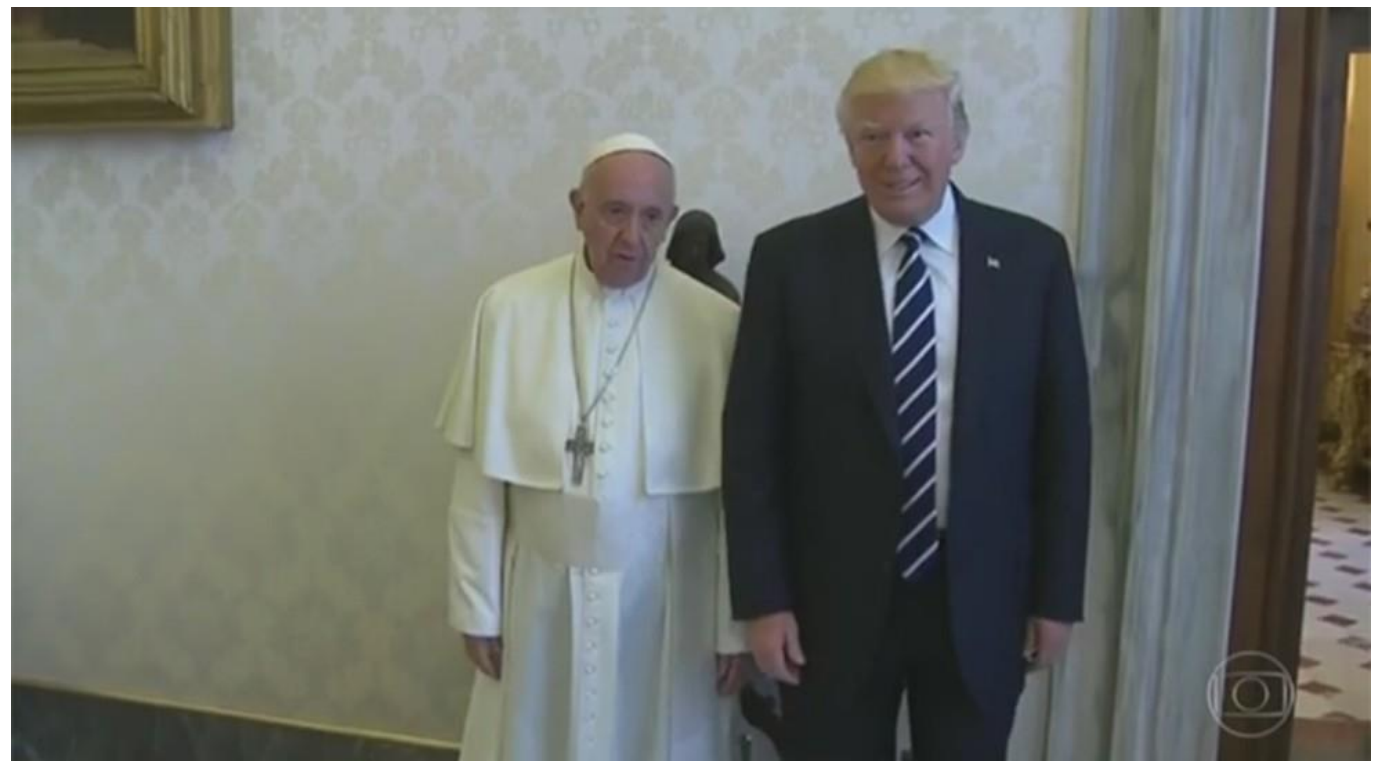

Foto do Papa Francisco e Donald Trump no Vaticano Fonte: http://g1.globo.com/e-ou-naoe/noticia/papa-francisco-deu-tapa-na-mao-de-donald-trump-nao-e-verdade.ghtml

Segundo informações da Rede Globo de Televisão, conforme fonte acima.

No momento da tal cena, no entanto, é dado um close na mão dos dois. E vários detalhes entregam a armação. É possível perceber que, no primeiro momento da imagem, não há uma mesa como a que aparece atrás dos personagens. A manga da camisa de Trump também aparece bastante na cena do tapa, mas está imperceptível nas tomadas reais, tanto na anterior quanto na posterior. Os botões da roupa do Papa também têm uma distância diferente entre si na cena do tapa se comparados aos botões da roupa na imagem verídica. $\mathrm{O}$ papel de parede é outro fator que denuncia a falsidade. 
A produção e a propagação de fake news criou a necessidade de verificar as informações. Fact-checking é "uma checagem de fatos, isto é, um confrontamento de histórias com dados, pesquisas e registros" (PUBLICA, 2017). É uma ferramenta para combater as notícias falsas.

No Brasil podemos citar a agência Lupa e o projeto Truco - da Agência Publica - que verificam notícias que circulam na rede e estabelecem classificações após pesquisa e análise variando entre verdadeiro, contraditório, discutível, plausível, exagerado, distorcido, falso, etc.

\section{3 - Aderência e propagação: modelos de distribuição e circulação na rede}

Propagabilidade e aderência são noções para explicar a lógica social e as práticas culturais que favorecem e popularizam as plataformas e ferramentas de comunicação online a partir da participação dos públicos conforme propõem Jenkins, Green e Ford (2015).

A relevância dos memes, selfies e fake news na comunicação contemporânea ocorre principalmente pela sua capacidade de propagação e circulação, modelo híbrido e emergente no qual o público pode moldar, compartilhar, reconfigurar e remixar conteúdos de mídia. A distribuição, modelo de aderência, diz respeito ao conteúdo controlado por interesses institucionais e comerciais.

Para JENKINS (2009, p. 29) circulação e distribuição referem-se a modelos de compartilhamento “onde as velhas e novas mídias colidem, onde a mídia corporativa e mídia alternativa se cruzam, onde o poder do produtor de mídia e o poder do consumidor interagem de maneiras imprevisíveis". Ainda segundo o autor,

As mídias corporativas reconhecem o valor e a ameaça da participação dos fãs. Produtores e anunciantes falam hoje das lovermarks reconhecendo a importância da participação do público em conteúdos de mídia. Os consumidores estão usando a net para se envolverem com o que admiram, entendem esse como um espaço democrático e de ações coletivas. A convergência alternativa tem impulsionado mudanças na paisagem midiática. A realidade é dual: de um lado a postura proibitiva tenta impedir participação não autorizada; do outro as cooperativas querem conquistar para si criadores alternativos (p. 235).

Retomando o exemplo sobre o memes com o presidente Michel Timer e a notificação da Secretaria de Imprensa podemos verificar como os modelos de aderência e de 
propagabilidade, mídia corporativa e mídia alternativa, interagem na rede e qual o papel dos interagentes nesse processo.

A atitude da Secretaria de Imprensa da Presidência da República foi uma tentativa de manter o controle sobre os conteúdos referentes à imagem do presidente que por sua vez representa a imagem institucional do governo. É uma tendência da comunicação governamental, embora esta adote diferentes sistemas de representação digital, manter a circulação centralizada nas fontes consideradas oficiais.

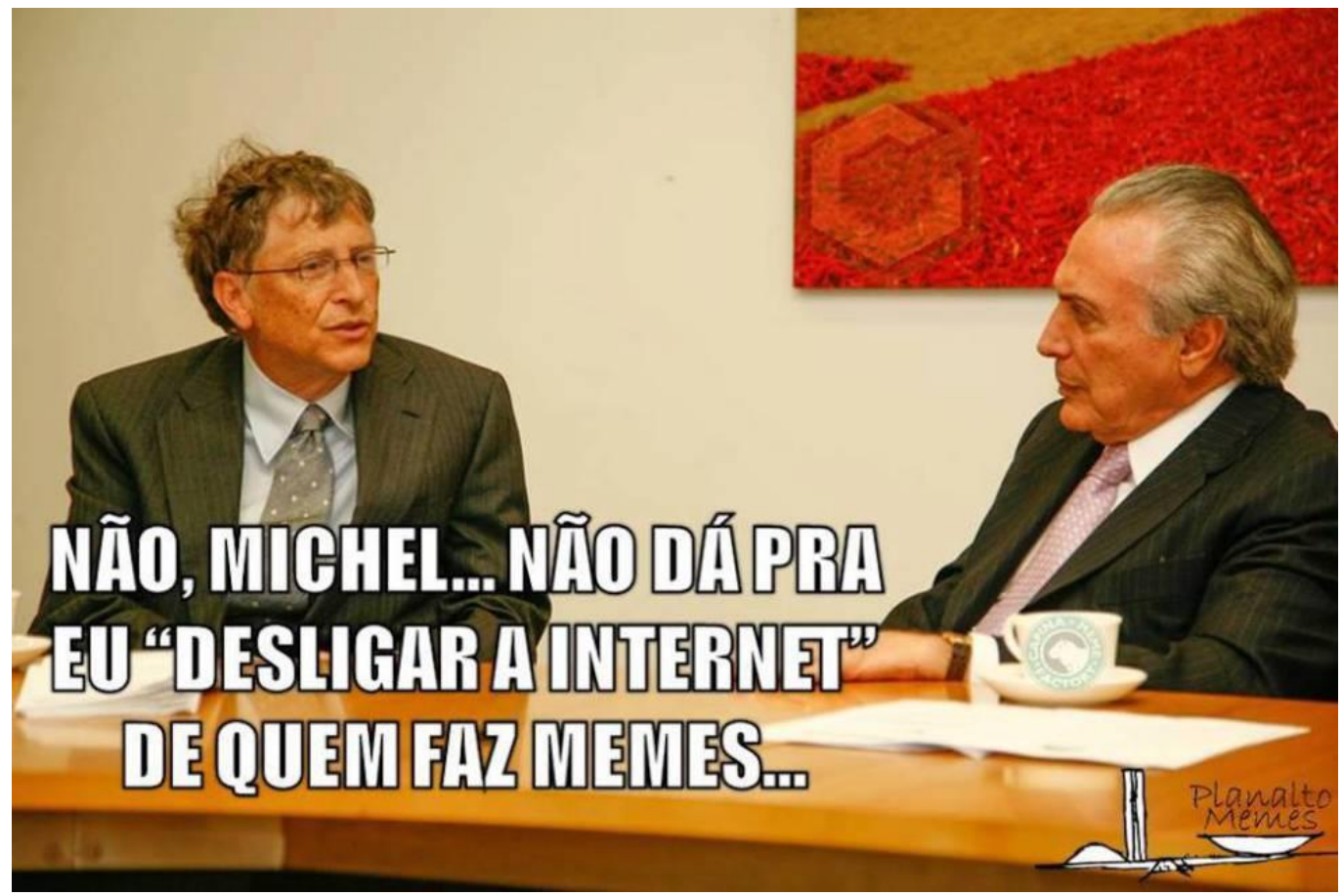

Meme - Temer e os Memes

Fonte: http://comunicacaoepolitica.com.br/blog/2017/05/a-guerra-de-temer-contra-os-memes/

No modelo de propagação os textos são "apropriáveis" e circulam de forma dispersa na rede como são os memes. Além dos recursos técnicos das plataformas digitais que facilitam a circulação desse conteúdo, o que impulsiona o compartilhamento é a troca de bytes significativos entre indivíduos através de suas conexões sociais (JENKINS; GREEN; FORD, 2015)

Portanto, memes, selfies e fake news são produções da cultura participativa que escapam ao controle da mídia corporativa, do governo, das empresas que por um lado desejam o apoio e participação criativa desses públicos quando alinhados aos seus propósitos e, por outro, a restrição ou punição quando entendem a participação deles como nociva. 
RELACult - Revista Latino-Americana de Estudos em Cultura e Sociedade

Revista Latinoamericana de Estudios en Cultura y Sociedad | Latin American Journal of Studies in Culture and Society V. 03, ed. especial, dez., 2017, artigo no 856 | relacult.claec.org | e-ISSN: 2525-7870

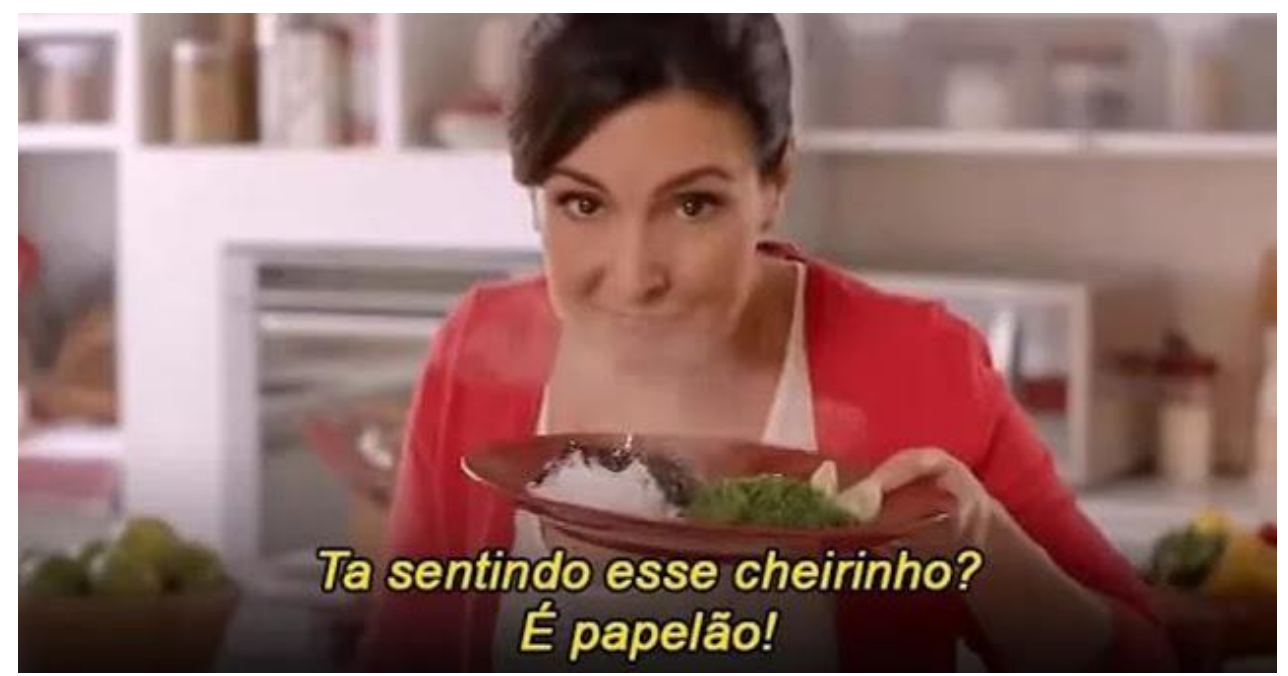

Meme - Friboi e Operação Carne Fraca com Fátima Bernardes Fonte: http://www.laudenir.com.br/2017/03/carne-fraca.html

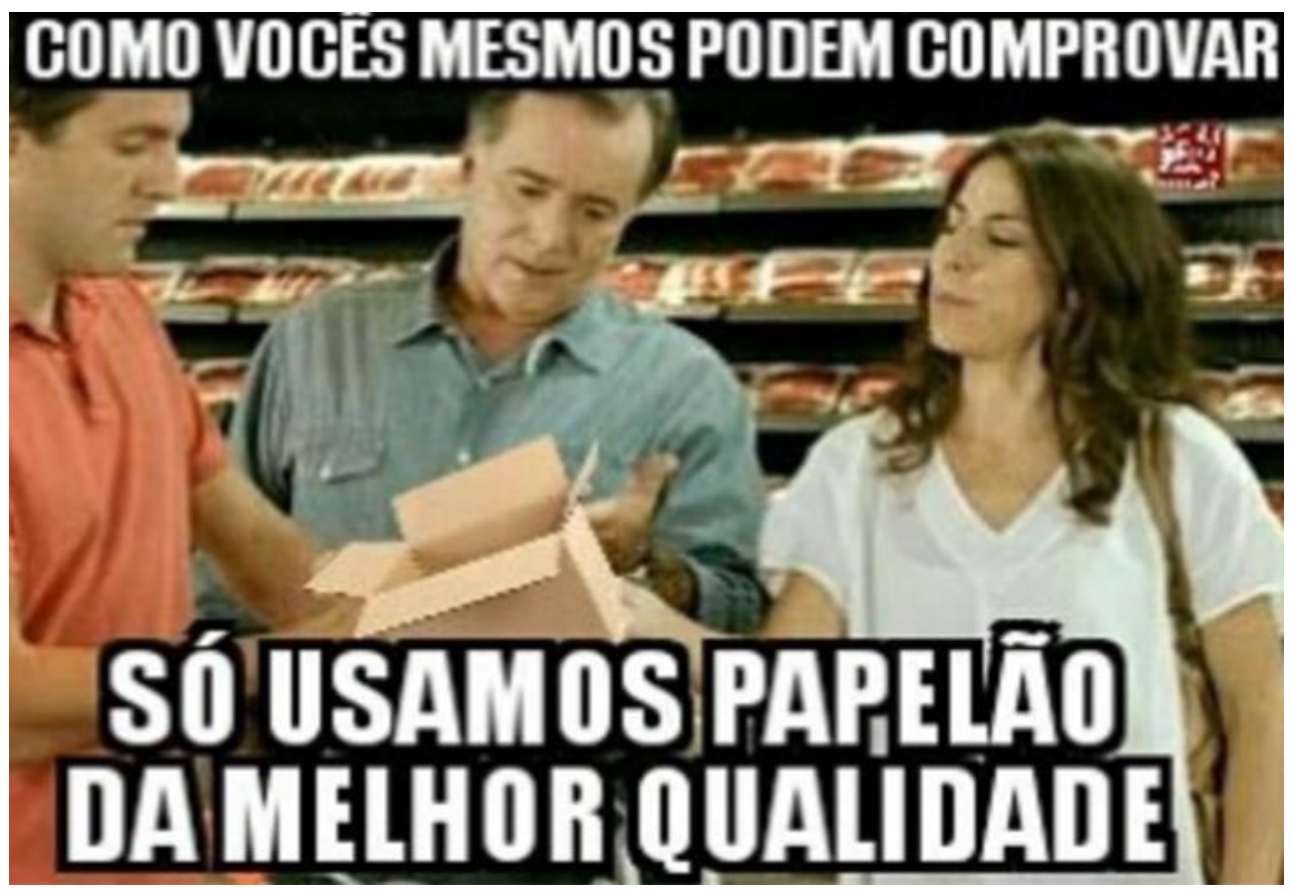

Meme - Friboi e Operação Carne Fraca com Tony Ramos Fonte: http://www.laudenir.com.br/2017/03/carne-fraca.html

Outro ponto sobre a propagação diz respeito a colaboração de papéis entre produtores e consumidores de conteúdo. Não há como distinguir um papel do outro nesse contexto. Embora a Secretaria de Imprensa da Presidência da República tenha notificado alguns sites de humor sobre o uso das fotos oficiais, em alguns casos não há como saber quem são os autores dessas produções porque os sites possuem inúmeros colaboradores e às vezes apenas compartilham conteúdos. 


\section{Considerações}

Em tempo de pós-verdades a produção e circulação de memes, selfies e fake news, conteúdos orientados visualmente, facilitam a socialização de crenças e valores. A veracidade das informações tem menos importância e relevância frente ao número de visualizações, comentários e compartilhamentos. Por isso, as fake news despertam preocupações com os profissionais da área de jornalismo, personalidades públicas e empresas porque elas têm o potencial tanto de causar impacto positivo quanto negativo na opinião pública dependendo da visibilidade alcançada.

O apelo a emoção das mensagens impulsiona a propagação dos memes, quase sempre em tom de humor, sobre os mais diversos assuntos e em constante atualização acompanhando a dinamicidade do cotidiano. Qualquer elemento cultural está sujeito a apropriação e, por conseguinte, ser transformado em meme: desde personagens fictícios até figuras públicas importantes.

As selfies, enquanto mídia, funcionam de forma semelhante na socialização de crenças. Contudo, abandonam o anonimato - deixam de ser um número de IP - para usar a própria imagem como parte da mensagem.

Seja no cômico dos memes, no eu das selfies ou na pós-verdade das fake news vivenciamos as diversas possibilidades comunicacionais que permeiam a cibercultura. A liberdade para manipular e remodelar as imagens a partir da cultura participativa dos interagentes, facilitada pelas plataformas digitais, atribui a esses signos o poder de compartilhar valores, construir sentidos e comunicar de maneiras imprevisíveis. 


\section{REFERÊNCIAS}

ACCIOLY, Maria Inês. Isso é simulação: a estratégia do efeito real. Rio de Janeiro: E-papers, 2010.

BOSI, Alfredo. Reflexões sobre a arte. São Paulo: Ática, 1999.

FAUSING, Bent. Self-mídia: O self, o rosto, as mídias e os selfies. Discurso proferido na Conferência Internacional sobre Ciência das Imagens Sensórias, Sassari, 2004.

JENKINS, Henry. Cultura da convergência. 2. ed. São Paulo: Aleph, 2009.

JENKINS, Henry; GREEN, Joshua; FORD, Sam. Cultura da Conexão. Criando valor e significado por meio da mídia propagável. São Paulo: Aleph, 2014.

JOLY, Martine. Introdução à análise da imagem. Campinas: Papirus, 1996.

MUSEU DO MEME.

REVISTA UNO, A era da pós-verdade: realidade x percepção.

SANTAELLA, Lúcia. O que é semiótica. São Paulo: Brasiliense, 1983.

SANTAELLA, Lúcia; NÖTH, Winfried. Imagem: cognição, semiótica e mídia. São Paulo: Iluminuras, 1998. 